\title{
Teacher and Student Evaluations of Project-Based Instruction
}

\section{Gulbahar H. Beckett}

Project-based instruction has gained some popularity in general education and in second-language (L2) education. However, a review of the literature shows discrepancies between teachers' and students' evaluations of this activity. For example, general education teachers and students find that project-based instruction creates opportunities for in-depth learning of subject-matter content, which fosters student independence and problem-solving skills. However, English as a Second Language (ESL) teachers' and students' evaluations show mixed results. Although some anecdotal reports and one systematic research study show ESL teachers endorsing project-based instruction because it provides opportunities for comprehensible output and integrated language teaching, there is evidence that ESL students and at least one ESL teacher are frustrated by this form of instruction. These students felt that project-based instruction prevented them from learning from the teacher and textbooks and from focusing on language skills. The ESL teacher felt a loss of student respect and noted a drop in student attendance. These discrepancies are discussed from philosophical, cultural, and linguistic perspectives. Recommendations for research and pedagogy are proposed. For example, it is suggested that a framework be developed to aid ESL teachers in assisting their multicultural students to understand the benefits of project-based instruction in L2 learning.

La pédagogie à base de projets s'est répandue dans le domaine de l'éducation en général ainsi qu'en enseignement en langue seconde. Toutefois, une revue de la littérature révèle la présence d'écarts entre les évaluations que font les enseignants de cette pédagogie et celle qu'en font les étudiants. Par exemple, les enseignants et les étudiants dans les cours réguliers estiment que la pédagogie à base de projets crée des occasions pour l'apprentissage approfondi du contenu en même temps qu'elle encourage l'indépendance des étudiants et le développement d'aptitudes à résoudre des problèmes. Les résultats des évaluations par les enseignants et les étudiants en anglais langue seconde (ALS) sont, par contre, mixtes. Alors que certains rapports empiriques et une recherche systématique indiquent que les enseignants en ALS appuient la pédagogie à base de projets parce qu'elle génère des occasions tant pour les productions compréhensibles que pour l'enseignement intégré des langues, il existe des preuves que des étudiants en ALS et au moins un enseignant du domaine sont frustrés par cette stratégie pédagogique. Ces étudiants estimaient que, d'une part, la pédagogie par projets les empêchait 
d'apprendre de l'enseignant et des manuels de classe et que, d'autre part, elle détournait l'attention des habiletés langagières. L'enseignant en ALS a perçu une baisse dans le respect que portaient les étudiants à l'apprentissage et a noté que ceux-ci s'absentaient plus souvent. L'auteur discute de ces divergences dans des perspectives philosophique, culturelle et linguistique, et offre des recommandations touchant la recherche et la pédagogie. Par exemple, il propose le développement d'un cadre qui aiderait les enseignants en ALS à faire comprendre à leurs étudiants multiculturels les avantages qu'offre la pédagogie à projets dans l'apprentissage d'une langue seconde.

\section{Background}

According to Adderley et al. (1975), Alberty (1927), and Holt (1994), projectbased instruction was first conceived of by the efficiency expert David Snedden to teach science in United States vocational agriculture classes. It was later developed and popularized for teachers by John Dewey's student (and later colleague) William Heard Kilpatrick, mainly through his 1918 pamphlet The Project Method. This was Kilpatrick's reconstruction of Dewey's problem method of teaching (Brubacher, 1947). The problem method called for learning from experience by solving real-life problems. It was seen as an alternative to the traditional teacher-centered way of teaching-learning (Cremin, 1964). Dewey's problem method was based on action as an expression of a basic empirical process that is organized and guided by activity and the questions it raises. The Project Method, then, involves students creating knowledge in order to solve problems that arise while they are engaged in purposeful, real-world activities (Dionne \& Horth, 1994).

Project-based instruction was introduced into second-language (L2) education in response to perceived inadequacies in Krashen's (1981) input hypothesis. Krashen claimed that comprehensible input is the most important variable in second-language acquisition. He argued that L2 learners need extensive exposure to the target language, as is the case when children learn their first language. However, Swain's (1985) evaluation of Canadian French immersion students' learning showed that comprehensible input alone is insufficient. Swain's study showed that years of comprehensible input did not enable her participants to achieve native-like competence in French, and this led her to propose that L2 learners need to produce comprehensible output through meaningful interaction with native speakers. In order to produce comprehensible output, Swain concluded that students needed a variety of communicative opportunities where they could engage in meaningful negotiation and interaction with native speakers in French cultural settings. This change in perspective was evidenced in the popularity of Brumfit's (1984) project-based communicative language teaching methodology. Hence project-based instruction has been applied to provide L2 learners 
(e.g., ESL learners) with opportunities to interact and communicate with each other and with native speakers of the target language in authentic contexts (Candlin, Carter, Legutke, Semuda, \& Hanson, 1988; Fried-Booth, 1986; Gardner, 1995; Hilton-Jones, 1988; Legutke \& Thomas, 1991; Stoller, 1997).

\section{Definitions}

A variety of terms such as project work (Shoring, 1990), project method (Kilpatrick, 1926), project approach (Diffily, 1996), project-oriented approach (Carter \& Thomas, 1986) and project-based learning (Peterson \& Myer, 1995) are used in general education and in the L2 education literature. These terms are used interchangeably with project-based instruction in this article. For the purpose of this article, a project is defined as a long-term (several weeks) activity that involves a variety of individual or cooperative tasks such as developing a research plan and questions, and implementing the plan through empirical or document research that includes collecting, analyzing, and reporting data orally and/or in writing. Also in this article, L2 education is defined broadly to include foreign language education.

\section{Benefits of Project-Based Instruction}

Project-based instruction is exploratory in nature. What students learn during their project work cannot always be anticipated in advance. Nevertheless, both general education and L2 education literature list a number of benefits for project-based instruction. The major benefits listed in the general education literature include opportunities that it provides for intrinsically motivating students to learn, fostering problem-solving, and developing independent and cooperative working skills. It is also believed that projectbased instruction allows students to develop critical thinking and decisionmaking skills and engage in in-depth learning of subject matter (Adderly et al., 1975; Berliner, 1992; Krajcik, Blumenfeld, Marx, \& Soloway, 1994; Ladewski, Krajcik, \& Harvey, 1994; Vithal, Christiansen, \& Skovsmose, 1995).

In the second-language acquisition (SLA) literature, there is occasional mention of fostering analytical and management skills through project work (Gardner, 1995; Coleman, 1992), but the emphasis is mainly on the opportunities that project work can provide for comprehensible output. For example, Brumfit (1984) claims that project-based instruction is beneficial for L2 education because it has the potential to provide students with the opportunity to develop accuracy and fluency through "emphasis on integrated projects" that arise "from the communicative needs of students within the framework of the project" (p. 123). Fried-Booth (1986) and Candlin et al. (1988) also believe that organizing projects is an effective way to create opportunities for L2 learners to develop their abilities in the target language by interacting and 
communicating with each other and with native speakers in authentic contexts.

\section{Research Literature on Project-Based Instruction}

\section{General Education}

As an educational activity, project-based instruction has been revived (Beckett, 1999). Most of these efforts are rooted in Dewey's ideas, reforms in the 1960s, and in recent efforts of the 1990s (Polman, 2000). As a result, a number of studies have been conducted. This section of the article reviews some of this literature on teacher and student evaluations of project work in general education.

\section{Teacher Evaluations}

Several studies have explored how general education teachers evaluate project- based instruction. For example, Ladewski et al. (1994) examined one grade 6 science teacher's attempt to understand and implement projectbased instruction in the US. Connie (pseudonym) taught a language arts and reading class in addition to her three science classes in a middle school of approximately 750 students in an economically and ethnically diverse city. When she started learning to teach through project-based instruction, Connie had four years of science teaching experience. She was familiar and comfortable with hands-on student activities. Connie was videotaped and interviewed "weekly or bi-weekly" (p. 503) while implementing two projects (one on water, the other on acid rain) that lasted six to eight weeks. Analysis of the videotaped and interview data revealed that Connie encountered some difficulties in classroom management in large-group activities (the students incinerated a computer), but in general she enjoyed teaching project-based science. Connie was attracted to features of project-based science such as using computing and telecommunication tools, investigative hands-on activities, and authentic real-world questions. She thought the hands-on activities enhanced students' understanding of the science curriculum. She also thought project-based science enabled her to see new possibilities in teaching, to develop new teaching strategies, and to refine her existing strategies.

Krajcik et al. (1994) report on a group of 11 experienced US science teachers ( 10 middle school and 1 elementary) learning the project approach to teaching. One of the research goals in this study was to investigate the challenges the teachers might face in learning to implement project-based instruction. The analyses of the videotaped observations, informal interviews, and teachers' reflection journals during their implementation of two six- to eight-week projects showed that the teachers liked teaching science through the project approach. They reported that compared with traditional methods, project-based science was more effective in promoting critical thinking, observation, and group work skills. The teachers said that in 
project-based science individual student thinking was continually affected by the input of others. Students were pushed to consider increasingly broader perspectives, instead of narrowing their thinking as the unit progressed.

In four case studies, Marx et al. (1994) explored how four experienced US middle-grade teachers, Becky, Dorothy, Bill, and George (pseudonyms), learned to teach project-based science. Becky was an experienced teacher with a master's degree. At the time of the study she taught a class of 24 grade 6 students in a large school in an affluent college town. Dorothy, a teacher with 13 years experience, taught science to grades 5,6 , and 7 students. The number of students and the setting of her school at the time of the study is not provided. Bill was an experienced science teacher who had over 20 years of science and math teaching experience. During the study year Bill taught science to a class of 22 grade 6 students in a middle school located in a relatively affluent suburb of Detroit. George, a teacher with 19 years of experience, taught grade 8 in a middle school located in a working-class community in southern Michigan. Data obtained through observations of these teachers implementing two projects each and interviews during and after the project work revealed that although they had some difficulties making the transition to a new way of teaching, especially one that gives ownership to the students, they endorsed project-based instruction. They reported discovering project-based instruction resulting in more active involvement, more independence from teachers, and more cooperation among students. They also reported notable improvements in students' learning of new concepts. Students learned new concepts faster, retained them longer, and were able to use them in class discussions.

Vithal et al. (1995) studied teacher and student evaluations of a projectbased mathematics program in a Danish university. According to the authors, studies at this university are problem-centered, where all students work in project groups that function as work units. A supervisor is assigned to each group, which consists of four to five students who are required to conduct projects on topics chosen by themselves along with their supervisors. These projects account for $50 \%$ of the study time. Interview data obtained from six supervisors (three experienced, two novice, and one foreign guest) and discussions with a wide variety of staff (details not provided) showed positive evaluations for project-based instruction. The participants thought a balanced project-based mathematics program was appropriate for their students because it allowed them to learn mathematics in depth as researchers, which they said was difficult to do using a lecture approach. 


\section{Student Evaluations}

Studies of general education student evaluations of project-based instruction include Owens (1997), Peterson and Myer (1995), Ramey (1997), and Renuka, Christiansen, and Skovsmose (1995). These studies found that most students wholeheartedly endorse project-based instruction. For example, Owens studied 73 grades 4,5 , and 6 students and their three teachers in the US Midwest to find the process and product of student engagement in a multiage, project-based, technology-supported classroom. Data from her fieldnotes of 55 school days, interviews with students and teachers, and project artifact analyses showed that students liked project-based instruction, especially because it gave them access to the World Wide Web, educational CD-ROMS, and word-processing software. Students developed ownership of their learning, gathered around the computers, helped each other, and shared information about their projects.

Peterson and Myer (1995) conducted a comparative study of collaborative project and traditional classes studying Community Agency Counseling: Programs, Issues, and Policies in a university in the US. Their findings showed that the project students believed their classes helped them to understand how agencies work and provided opportunities for them to learn the basics of starting and running an agency.

For all 16 Likert-type items on the scale used for course evaluations, the median ratings from the classes using collaborative projects were higher than the mean of the ratings from the three classes in which the traditional format was used. (p. 155)

Ramey (1997) studied a group of US high school students who voluntarily enrolled in a project-based calculus class. She wished to find out why these students chose to be in the project class rather than the traditional calculus class. The student participants in the study reported that they favored project-based calculus because they enjoyed the hands-on application of mathematics as well as the extensive use of technology. They believed project-based instruction enabled them to find real-world applications for their calculus. They believed they had improved their problem-solving and critical thinking skills by conducting projects. They also believed projectbased calculus was intrinsically motivating and helped develop their skills for working in cooperative group settings.

Renuka et al. (1995) explored how teachers and students interpreted project-based mathematics education in a Danish university where students are required to engage in project work for $50 \%$ of their time. They interviewed three groups of students (4-5 students in each group). Two of these groups consisted of sophomore mathematics students, and one group was master's students in their final year of study. The results of the study revealed that although some students (exact number not provided) wished 
they could learn mathematics "just for its own sake" (p. 206) rather than having to worry about applying it to real-world situations through project work, the student participants in this study in general endorsed projectbased instruction. They reported that in project work they could "do mathematics," could apply mathematics to other fields ("can see the connection"), and could learn from the process itself (e.g., problem-solving skills). They also said that project-based instruction allowed them to learn math thoroughly through in-depth study.

\section{Second-Language Education}

Compared with general education, research on project-based work in L2 education is rare. Most of the available literature consists of anecdotal reports of how language teachers organized project work for the purpose of secondlanguage acquisition. Only two doctoral-level research studies have been found. This section of the article reviews the literature on L2 teacher and student evaluations of project-based instruction.

\section{Teacher evaluations.}

In an anecdotal report, Carter and Thomas (1986) discuss their successful experience in organizing various small projects that included ESL students teaching native English-speaking elementary students in the United Kingdom. They were pleased that their ESL students contributed to crosscultural knowledge by teaching about different cultures as part of their projects. Gardner (1995) reports on a project he organized in an English course in the University of Hong Kong. The project was intended to create opportunities for students to exercise their academic listening comprehension and note-taking skills. Gardner was pleased that the project helped his students not only improve their listening and note-taking skills, but also their writing skills. Hilton-Jones (1988) recounts a successful six-week projectbased English-language course she taught in the UK to a group of teenagers from West Germany. She considers her experience a success because she found that the project-based activity created opportunities for her students to practice listening, speaking, reading, and writing skills in English and enabled them to see their language learning needs.

In one of the two systematic research studies, Beckett (1999) investigated the implementation of project-based instruction in a Canadian secondary school ESL class. Specifically, the study examined ESL teacher goals for, and ESL teacher and student evaluations of, project-based instruction. Analysis of data collected through observations and interviews of two teachers, Ms. Jones and Ms. Brown (both pseudonyms), indicated that the teachers favored project-based instruction because it allowed them to take an integrated approach to language teaching (i.e., integrating language, content, and skills). It allowed them to foster critical thinking and problem-solving skills and pro- 
mote independent as well as cooperative learning skills. The teachers were impressed by the creative and in-depth work that their students did for their projects. They evaluated project-based instruction favorably also because they thought it provided contexts for their students to learn English functionally (i.e., by listening to, speaking, reading, and writing English to learn). The teachers were delighted that project activities allowed for unexpected learning to take place. For example, by engaging in project work, students were able to find out their strengths and weaknesses as learners.

In the only other systematic study, Eyring (1989) found teacher evaluations to be mixed. Eyring designed her study to document one US teacher's experience implementing project-based instruction for the first time, and to examine students' attitudinal and proficiency responses to this form of instruction. Susan (pseudonym), the teacher participant in the study, indicated that she was impressed by the oral presentation skills that all her students gained from their experience of project-based instruction and by the fact that they designed a real-life activity as part of the project, writing a thank-you letter to some guest speakers. However, she also reported frustrations and tensions. She found that negotiating the curriculum with the students regarding project-based instruction was complex and demanding. She felt that it was difficult to come to a consensus about worthwhile topics and assignments. The students did not participate enthusiastically in the course planning. They withdrew, seemed apathetic, and at times made a conscious choice not to participate. Although some students supported the ideas generated, others expressed antagonism, and still others were not interested in the idea of project work at all. Susan noticed that more of her project group students were late or absent more often compared with those in previous classes she taught using more traditional methods. Some students complained that they were not learning enough academic skills while conducting projects.

As Susan had never received such a lukewarm response from her students before, she felt overwhelmed, discouraged, and underappreciated. She felt that she did not have respect shown to her by previous students, although she was working just as hard to manage classroom activities. Students did not recognize, appreciate, or accept input that was offered to them in a nontraditional form. Some students ignored Susan when she tried to help. She was not pleased, for example, when she noticed that some of the reading material she brought to class was not consulted. These responses from the students led Susan to question her ability to continue with the project while maintaining her students' respect. In the end she decided to "revert to more traditional, teacher-directed activities" (Eyring, 1989, p. 113), adding "regular ESL stuff," such as reading and grammar activities, to "give the students something concrete that they can say they have learned" ( $p$. 110). 


\section{Student Evaluations}

It is clear that the general education students in the studies reviewed above evaluated project-based instruction positively. However, L2 student evaluations are mixed. An anecdotal report from Coleman (1992) indicated some second-year French language students at Portsmouth Polytechnic in the UK enjoyed project-based instruction. Specifically, the students were asked to produce a 10-minute French-language video with a written dossier on a contemporary French topic and share their video in class on completion. After students completed producing and sharing their videos, they were invited to provide feedback about the project-based approach to learning French. The analysis of student feedback showed that they enjoyed a nontraditional language learning experience that provided them independence. Students reported that through their project work they learned about teamwork and improved their reading, writing, speaking, and listening skills.

However, according to two systematic research studies (Beckett, 1999; Eyring, 1989), although ESL students carried out their projects successfully and impressively, their evaluations expressed dilemmas, frustrations, and tensions. The student participants in the study by Beckett (1999) included 73 students from Taiwan, Hong Kong, and China. They were observed during two project units and interviewed about their evaluations of project-based instruction in general at the end of their project work. According to observations and analysis of students' written work, the student participants in this study learned a tremendous amount of knowledge and skills by conducting projects. They learned Canadian school and social cultures, and they learned and used the language-discourse of research (e.g., participants, hypothesis, interviews, findings, and discussions). Students worked cooperatively, made decisions, and learned how to do research through interviews and library document analysis. They also learned social studies and other curricular content and developed writing skills and learned how to use computers, library catalogs, and microfiche, all through English. Yet the analysis of observations, interviews, and students' written work found student evaluations of project-based instruction to be mixed. That is, of the 73 students, only $18 \%$ said they liked project-based instruction, whereas $25 \%$ had mixed feelings, and $57 \%$ said they did not like it.

The students who evaluated project-based instruction positively said that they liked it because doing projects was fun and because projects created opportunities for them to learn research, computer, writing, and communication skills. Those who had mixed feelings reported that they liked project work because it made them think, allowed them to gain knowledge in-depth, and to learn research and presentation skills; they disliked it because it is time-consuming (i.e., it takes too long to carry out a project). The students who did not favor project-based instruction said projects were "too much work." They said that the oral presentation aspect of project work is "too 
hard" for them because it made them nervous about their communicative competence. Other aspects mentioned as difficult included identifying and reading appropriate references, understanding the major points, and integrating the information. These students also reported that they wished to focus on learning English separately from content and wanted teachers to teach from textbooks. They thought learning by themselves from other sources through project work distracted them from learning English from their teachers and textbooks.

Eyring (1989) not only examined one teacher's experience of implementing project work for the first time, she also examined 11 Asian, European, and Latin American students' attitudinal and proficiency responses to project-based instruction. Six of the 11 students were from Asia and five were from Europe and Latin America. Students were involved in identifying project topics and in planning, researching, discussing, writing up, and presenting their project work. The results of the study showed that although students made their own plans (regarding what, how, and when to do their projects) and seemed to have completed all the tasks as required, they felt a great deal of tension. They said that "allowing so much input and 'authority' was not good in an academic class" (p. 176). In other words, the students did not appreciate the power given to them to plan their own curriculum.

Many of the students reported a desire for a more traditional way of learning (e.g., learning from the teacher through lecture format and studying vocabulary and grammar points separately). When the students were asked to rate their favorite activities, the opportunity to talk to their teacher was rated highest, followed by learning to write essays and papers. Grammar lessons also received a high rating: Students specifically requested more grammar instruction. Traditional reading, writing, and grammar activities were considered the real work of learning English. When "a student who had been absent asked another student about what had ensued the day before, she was told only that they had a grammar lesson, which took 18 minutes of time; the fact that the remaining 87 minutes was spent discussing projects was not even mentioned" (Eyring, 1989, p. 189).

\section{Discussion of Discrepancies}

The literature indicates mixed findings in research that examines teacher and student evaluations of project-based instruction. The research on general education teacher evaluations shows that teachers enjoy this unconventional way of teaching. However, L2 teacher evaluations of project-based instruction are mixed. Although some anecdotal reports (Carter \& Thomas, 1986; Gardner, 1995; Hilton-Jones, 1988) and one systematic study (Beckett, 1999) suggest that some L2 teachers enjoy teaching through project-based instruction, Eyring's (1989) study shows a markedly different result. The teacher in Eyring's study reported tensions in implementing project work. What could 
have contributed to this discrepancy? Could this difference be due to Susan's insecurity organizing a project for the first time (Eyring, 1989), whereas Ms. Brown and Ms. Jones had several years' experience of project work (Beckett, 1999)? Could student evaluations explain this discrepancy?

Although the essence of the project method is wholehearted, purposeful activity on the part of the learner (Kilpatrick, 1918), little research has been conducted to explore how the learners evaluate project-based instruction. The available literature on student evaluations of project-based instruction suggests discrepancies between general education students' and ESL students' and between ESL teachers' and their students' evaluations of this activity. That is, although secondary and postsecondary general education students evaluated project-based instruction positively, their ESL counterparts did not wholeheartedly endorse project-based instruction despite their apparent success in project work. Although the teachers participating in the Beckett study evaluated this activity favorably, stating that they liked this form of teaching because it allowed them to teach ESL integratively with content and skills, their students expressed dilemmas and frustrations. The students thought this activity disallowed them from learning ESL as they used to learn it, that is, learning vocabulary, grammar, conversational English, and English composition, despite the fact that they did all these during their project work. The teachers in this study were pleased because project-based instruction created opportunities to foster independence among students, but their students said they wanted to learn from the teacher and the textbooks, not by conducting projects. The student participants in Eyring's (1989) study also reported frustrations about learning ESL through project work although their teacher thought they produced impressive work in their projects. The students in this study also appeared to consider separate grammar lessons to be more important than doing projects, although they conducted their project work by listening to, speaking, reading, and writing in English using grammar. The students also seemed to dislike the power given to them during project work. What can explain these discrepancies? Why did the students not see the benefits and value their project work afforded to them? Why did they think project work distracted them from learning English language when they conducted all their projects in English, thus not only learning and practicing their English, but also using English to learn? Why did the students participating in the Beckett study prefer to learn from teachers and textbooks as opposed to learning by themselves from other resources? Why did students participating in the Eyring study give a high rating to the opportunity to talk to the teacher? Why did they ask for traditional reading, writing, and grammar activities while they did all these for their projects? What prevented them from seeing and appreciating the reading, writing, and grammar activities that were involved in their project work? Why did the student participating 
in both Beckett's and Eyring's studies not appreciate the power given to them to develop independence?

Could philosophical differences (i.e., traditional vs. progressive education) account for these discrepancies as suggested by Hui (1998)? Superficially, such an explanation may seem possible. But if we look closely, the explanatory power of this model is limited. For example, one of the negative features of progressive education considered by opponents such as Hirsch (1996) is that progressive teachers do not have standards they require students to work toward. However, the Beckett (1999) study reported teachers having high standards and students reported project work to be "hard," not easy. Also, such an explanation may be misleading, because by using this philosophical model, we may be applying a North American template to a cross-cultural situation. It is possible that when the students in both Beckett's and Eyring's (1989) studies showed desire for more teacher-centered learning, they could be speaking from Chinese or Korean cultural perspectives that expect teachers (i.e., authorities) to be in charge and pass on knowledge from textbooks, not from a philosophical view of traditional education. Such an explanation may also account for the discrepancies found between the general education and L2 education students' evaluations of project-based instruction. That is, it is possible that the general education students evaluated this activity positively because they are used to student-centered (a major characteristic of the project-based instruction) North American educational culture, whereas their ESL counterparts may have been used to a more teacher-centered educational culture from their home countries (e.g., China as is the case in the Beckett study). But what can account for the discrepancies about teachers organizing project work to teach ESL in an integrated manner through project work, whereas their students desired separate grammar and composition lessons? Is it possible that the teachers in these studies may have held a functional view of language and language teaching, whereas their students may have held a formalist point of view toward language and language teaching? The fact that the teachers in the Beckett study applied an integrated, meaning-based approach to their teaching of ESL, and their students complaining that they did not receive separate instructions for discrete language skills such as listening, speaking, reading, and writing seems to suggest that this could be the case. As discussed by Beckett, it is important that these discrepancies be explained from multiple theoretical perspectives, as any one of them would be inadequate for our understanding of these complex issues. The dilemmas reported by students in the Beckett study may be explained from a dilemmatic perspective suggested by Billig et al. (1988) and Liang (1998). That is, the students may have had mixed feelings about project-based instruction because project work, like everyday life, is complex and full of dilemmas. 


\section{Implications}

\section{Implications for Pedagogy}

Implications of this review for $\mathrm{L} 2$ teachers are that project-based instruction has a great potential for functional language teaching and learning. That is, they can use this approach to teach language, subject-matter content, and cognitive as well as social skills in an integrated manner (Mohan, 1986). But they need to understand that this approach to teaching may not be appreciated by all L2 learners at all times. They should be aware that because of different philosophical, cultural, and linguistic beliefs that their multicultural students may bring to their classes, they may encounter conflicts and tensions in their implementation of project work. However, they need to understand that these conflicts and tensions can and need to be managed should they arise. Teachers may have wonderful and important goals to achieve, but if their students do not see the benefit of what and how they are asked to learn, their goals cannot be achieved and their educational agendas may be jeopardized. One way to manage these conflicts and tensions is to assist students to see the potential benefits of project-based instruction through an accepted systematic framework that helps students see the kinds of learning that can take place through project work. For an example of such a framework, see Beckett, Mohan, and Slater (2000).

Meanwhile, L2 teachers should recognize that there are divergent beliefs and interpretations of education in general and L2 education in particular. Such beliefs and interpretations can have lasting effects on students. L2 teachers can see schools as learning organizations (Senge, 1990) where different perspectives are shared among teachers, students, parents, and administrators who need to learn "how to learn" together (p. 3). Some ways to do this can include ongoing "diversity dialogues" (Taylor, 1997; 1999) where teachers, students, parents, administrators, and researchers work together to identify and manage dilemmas and tensions and see them as a driving force for change and improvement.

\section{Implications for Further Research}

Further research is needed to examine the implementation of project-based instruction at various levels of L2 instruction in different contexts. More specifically, researchers should study ESL teacher and student experiences with the process and product of project-based instruction, noting difficulties and successes. Research may also be conducted to examine administrators' and parents' evaluations of project-based instruction and explore the reasons for discrepancies in their evaluations if there are any. L2 researchers and teachers need to work together to develop a framework that aids teachers in assisting their students to understand and benefit from the many potentials of this activity in their learning. 


\section{Acknowledgments}

I would like to take this opportunity to thank Dr. Patricia Duff for introducing to me the only doctoral thesis available on project-based instruction (Eyring, 1989) when I was desperately searching for literature. I would also like to thank Dr. Pat Mathews and Dr. Sandra Kouritzin, and the anonymous reviewers for their helpful suggestions.

\section{The Author}

Gulbahar H. Beckett studied and worked in Canada before taking up a tenure-track assistant professor position at the University of Cincinnati, Ohio. She is a recipient of a 2001-2003 SSHRC Postdoctoral Fellowship. Her research interests include L2 students' discourse development through project-based activities, computer-assisted language learning, and L2 language socialization.

\section{References}

Adderly, K., Ashwin, C., Bradbury, P., Freeman, J., Goodlad, S., Greene, J. et al. (1975). The project method in higher education. London: Society for Research into Higher Education.

Alberty, H.B. (1927). A study of the project method in education. Columbus, OH: Ohio State University Press.

Beckett, G.H. (1999). Project-based instruction in a Canadian secondary school's ESL classes: Goals and evaluations. Unpublished doctoral dissertation, University of British Columbia.

Beckett, G.H., Mohan, B., \& Slater, T. (2000). Framework for project-based instruction. Poster session presented to the TESOL Annual Convention, Vancouver.

Berliner, D.C. (1992). Redesigning classroom activities for the future. Educational Technology, $32(10), 7-13$.

Billig, M., Condor, S., Edwards, D., Gane, M., Middleton, D., \& Radley, A. (1988). Ideological dilemmas: A social psychology of everyday thinking. London: Sage Publications.

Brubacher, J.S. (1947). The history of the problems of education. New York: McGraw-Hill.

Brumfit, C. (1984). Communicative methodology in language teaching. London: Cambridge University Press.

Candlin, C., Carter, G., Legutke, M., Semuda, V., \& Hanson, S. (1988, March). Experiential learning: Theory into practice. Paper presented to the TESOL Colloquium, Chicago.

Carter, G., \& Thomas, H. (1986). "Dear brown eyes": Experiential learning in a project oriented approach. ELT Journal, 40(3), 196-204.

Coleman, J.A. (1992). Project-based learning, transferable skills, information technology and video. Language Learning Journal, 5, 35-37.

Cremin, L.A. (1964). The transformation of the school: Progressivism in American education 1876-1957. New York: Vintage Books.

Dewey, J. (1926). Democracy and education: An introduction to the philosophy of education. New York: Macmillan.

Dewey, J., \& Dewey, E. (1915). Schools of to-morrow. London: J.M. Dent.

Diffily, D. (1996). The project approach: A museum exhibit created by kindergartners. Young Children, 51(2), 150-158.

Dionne, H., \& Horth. R. (1994). Challenges of literacy and development in rural Quebec. In Alpha 94: Literacy and cultural development strategies in rural areas (Clearinghouse No. RC026246). Washington, DC: Department of Education. (ERIC Document Reproduction Services No. ED 386 354)

Eyring, J.L. (1989). Teacher experience and student responses in ESL project work instruction: A case study. Unpublished doctoral dissertation, University of California Los Angeles.

Fried-Booth, D.L. (1986). Project work. Oxford, UK: Oxford University Press.

Gardner, D. (1995). Student produced video documentary provides a real reason for using the target language. Language Learning Journal, 12, 54-56. 
Hilton-Jones, U. (1988). Project-based learning for foreign students in an English-speaking environment (Report No. FL017682). Washington DC: US Department of Education. (ERIC Document Reproduction Service No. ED 301054)

Hirsch, Jr., E.D. (1996). The schools we need: And why we don't have them? New York: Doubleday.

Holt, M. (1994). Dewey and the "cult of efficiency": Competing ideologies in collaborative pedagogies of the 1920s. Journal of Advanced Composition, 14(1),73-92.

Hui, H. (1998, March 11). Chinese lead traditional school drive: Parent group drafts nine guiding principles. Vancouver Courier, p. 11.

Kilpatrick, W.H. (1918). The project method. Teachers College Record, 19, 319-335.

Kilpatrick, W.H. (1926). Education for a changing civilization. Three lectures delivered on the Luther Laflin Kellogg Foundation at Rutgers University. New York: Macmillan.

Krajcik, J.S., Blumenfeld, P.C., Marx, R.W., \& Soloway, E. (1994). A collaborative model for helping middle grade science teachers learn project-based instruction. Elementary School Journal, 94, 483-497.

Krashen, S. (1981). Second language acquisition and second language learning. Oxford, UK: Pergamon Press.

Ladewski, B.G., Krajcik, J.S., \& Harvey, C.L. (1994). A middle grade science teacher's emerging understanding of project-based instruction. Elementary School Journal, 94, 499-515.

Legutke, M., \& Thomas, H. (1991). Process and experience in the language classroom. New York: Longman.

Liang, X. (1998). Dilemmas of cooperative learning: Chinese students in a Canadian school. Unpublished doctoral dissertation, University of British Columbia.

Marx, R.W., Blumenfeld, P.C., Krajcik, J.S., Blunk, M., Crawford, B., Kelly, B., \& Meyer, K.M. (1994). Enhancing project-based science: Experiences of four middle grade teachers. Elementary School Journal, 94, 517-538.

Mohan, B. (1986). Language and content. Reading, MA: Addison-Wesley.

Owens, R.F. (1997). Lighting fire: A descriptive case study of one multi-age, project-based, technology supported classroom (fourth-grade, sixth-grade). Unpublished doctoral dissertation, University of Illinois at Chicago.

Peterson, S.E., \& Myer, R.A. (1995). Innovative methods: The use of collaborative project-based learning in counselor education. Counselor Education and Supervision, 35, 151-158.

Polman, J.L. (2000). Designing project-based science: Creating learning through guided inquiry. New York: Teachers College Press.

Ramey, C.L. (1997). The effect of project-based learning on the achievement and attitude of calculus I students: $A$ case study. Unpublished doctoral dissertation, University of Missouri, Kansas City.

Renuka, V., Christiansen, I., \& Skovsmose, O. (1995). Project work in university mathematics education. Educational Studies in Mathematics, 29, 199-223.

Senge, P. (1990). The fifth discipline: The art and practice of the learning organization. New York: Currency Doubleday.

Shoring, N. (1995). Project work: Why should you include it in your teaching program? Australian Science Teachers Journal, 41(3), 28-29.

Stoller, F.L. (1997, October-December). Project work: A means to promote language content. FORUM, 35(4). Retrieved March 19, 2002, from http:/ / exchanges.state.gov/forum/vols/vol35/no4/p2.htm

Swain, M. (1985). Communicative competence: Some roles of comprehensible input and comprehensible output in its development. In S. Gass \& C. Madden (Eds.), Input in second language acquisition (pp. 235-253). Rowley, MA: Newbury House.

Taylor, C. (1997, September 21). Negotiating the difference. Interview conducted by CBC Radio, Toronto, Canada.

Taylor, C. (1999, March 25). Theories of modernity. Public lecture given at the University of British Columbia. Vancouver, Canada.

Vithal, R., Christiansen I., \& Skovsmose, O. (1995). Project work in university mathematics education: A Danish experience. Educational Studies in Mathematics, 29(2), 199-223. 